\title{
Reflets
}

Revue ontaroise d'intervention sociale et communautaire

\section{Faut pas chercher à comprendre}

\section{Carole Labrèche}

Volume 1, numéro 2, automne 1995

La santé communautaire en Ontario français : défis et espoirs

URI : https://id.erudit.org/iderudit/026081ar

DOI : https://doi.org/10.7202/026081ar

Aller au sommaire du numéro

Éditeur(s)

Reflets : Revue ontaroise d'intervention sociale et communautaire

ISSN

1203-4576 (imprimé)

1712-8498 (numérique)

Découvrir la revue

Citer ce document

Labrèche, C. (1995). Faut pas chercher à comprendre. Reflets, 1(2), 163-163.

https://doi.org/10.7202/026081ar

Tous droits réservés (C) Reflets : Revue ontaroise d'intervention sociale et communautaire, 1995

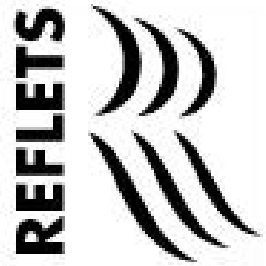

Ce document est protégé par la loi sur le droit d'auteur. L'utilisation des services d'Érudit (y compris la reproduction) est assujettie à sa politique d'utilisation que vous pouvez consulter en ligne.

https://apropos.erudit.org/fr/usagers/politique-dutilisation/ 


\section{Faut pas chercher à comprendre}

\section{C arole L abrèche}

Ici, c'est le bout de la solitude

Ici, les gens ont tellement souffert

Q u'ils ne sont plus personne

C'est un monde étrange où il faut

s'expliquer, s'exprimer, se défouler, se confier, pour enfin se guérir du besoin

de s'expliquer, de s'exprimer, de se défouler, de se confier.

Y paraît qu'il faut coller à ses émotions

$M$ ais encore là, y a une manière de le faire

Si tu pognes trop les nerfs

Ça risque de déplaire à l'équipe multidiscipli-nerfs!

L'autre jour, à I'hôpital

J'ai dit tout haut ce que je pensais tout bas:

«CI ON TUE LETEM PSEN ATTENDANT DE SETUER»

Ça pas pris de temps qu'on m'a demandé

des explications

La prochaine fois, je vais me fier à mon intuition

En psychiatrie, il y a une règle d'or à observer

U ne fois que tu tombes dans leurs pattes

Essaye donc pas de faire la «smatte». 